\title{
Overflowing the Measure: Cleopatra Unbound
}

\section{Sophie Chiari}

\section{(2) OpenEdition \\ Journals}

Electronic version

URL: http://journals.openedition.org/shakespeare/4397

DOI: $10.4000 /$ shakespeare.4397

ISSN: 2271-6424

\section{Publisher}

Société Française Shakespeare

\section{Electronic reference}

Sophie Chiari, «Overflowing the Measure: Cleopatra Unbound ", Actes des congrès de la Société

française Shakespeare [Online], 37 | 2019, Online since 03 January 2019, connection on 30 April 2019.

URL : http://journals.openedition.org/shakespeare/4397 ; DOI : 10.4000/shakespeare.4397

This text was automatically generated on 30 April 2019.

(C) SFS 


\title{
Overflowing the Measure: Cleopatra Unbound
}

\author{
Sophie Chiari
}

1 If multiple and sometimes diverging interpretations of the adjective "unbound" may be offered, in this article, I intend to associate the word both with the absence of limits ( Oxford English Dictionary, "unbound", adj. 3) and with a certain form of freedom, as the verb "to unbind" has meant "to loosen, open up or out, set free, detach" since at least 1577 (OED, "unbind", v., 1.b). ${ }^{1}$ My analysis will focus on the letting loose of Nature's forces in Anthony and Cleopatra, ${ }^{2}$ where the feelings and the passions of the two title-parts "[o]'erflo[w] the measure" (1.1.2). In the following development, special attention is thus paid to Cleopatra, Shakespeare's femme fatale whose mercurial temper reflected, in the early modern period, the Egyptian weather and environment. Anthony's desperate attempts at securing her love are doomed to failure precisely because the queen's intimate meteorology and bodily humours, fed by excess and overflowing, cannot be satiated. Of course, by contrast, Octavius Caesar seems the only one truly bound for moderation and thus, for governance. In the 1603 enriched edition of North's Plutarch, the "Life of Octavius Caesar Augustus" already emphasised Caesar's sobriety and made it clear that "[h]e was very modest and continent in all the parts of his life [...]. In his ordinarie diet he banished superfluity of meates; [...]. Also he drunke very little wine [...]". ${ }^{3}$ Significantly, in Shakespeare's play, he is a deeply rational man whose spirits can merely be warmed by a piece of good news ("But it would warm his spirits / To hear from me you had left Anthony", Thidias tells Cleopatra in 3.13.69-70). Yet his good qualities are not sufficient to make him the play's real hero as, for the audience, the tragedy's truly outstanding characters remain, from beginning to end, the glamorous Egyptian queen and her defeated Roman lover. Therefore, I intend to explore what makes the two titleparts larger than life in spite of their many drawbacks and weaknesses. In particular, in foregrounding Cleopatra's shiftiness, I aim at shedding fresh light on the play's general focus on the dissolution of things, a dimension found in Lucretius' De rerum natura (first century BC), a poetic repository of Epicurus' views of nature. 
2 In this perspective, it is worth noting that Epicureanism is clearly mentioned in the tragedy, albeit in a biased and ironical way, when Anthony suspects Lepidus of being "a very epicure" (2.7.52), i.e. a glutton. The playwright illustrates here the popular understanding of this philosophical trend, then often dismissed because considered dangerous. ${ }^{4}$ Yet, through Lucretian poetry, Epicureanism gradually found its way among early modern learned circles, especially among scholars who were interested in scientific and environmental matters. ${ }^{5}$ As a result, Epicurus' philosophy is being subtly rehabilitated in the play ${ }^{6}$ through Shakespeare's representation of an Egyptian universe set in motion by Venus/Cleopatra and characterised by its evanescence as much as by its "infinite variety" (2.2.243).

\section{The destructive and creative power of the Nile}

As a creature born out of the Nile's mud and slime, Cleopatra collapses all differences between the living and the dead, between wetness and dryness as well as between male and female. ${ }^{7}$ Slime, mud and earth in Anthony and Cleopatra provide an insight into the very principles of life in the east. As early as in the play's opening scene, a defiant Anthony comments on the naturally fertile Egyptian soil and exclaims: "Kingdoms are clay. Our dungy earth alike / Feeds beast as man. [...]" (1.1.37-38). For an early modern audience, the image of the "dungy earth" ${ }^{\text {m }}$ must, on the one hand, have called to mind the manure which traditionally fertilised England's arable lands ${ }^{9}$ while contributing, on the other, to refamiliarise Egypt as a version of rainy, muddy England..$^{10}$ As opposed to the "new heaven" (1.1.17) mentioned a few lines before, "clay" (connoting vulnerability) ${ }^{11}$ is what the Roman general must be satisfied with. More importantly, Anthony, in his speech, also refers to some sort of generative matrix levelling all living creatures. For Gabriel Egan, this overdetermined presence of an oozy fruitfulness makes love appear superior to mere fecundity since "the Earth's reproductive principle generates food", while Anthony and Cleopatra's "coupling is something better because non-reproductive". ${ }^{12}$ The muddy Nile would thus embody the reality principle, i.e. the need for reproduction, as opposed to the pleasure principle blindly and selfishly followed by the two lovers. Fundamentally linked to the feminine element and to Cleopatra's acting skills and metamorphic being, slime is endowed with the power to sully and smear as much as to shape and give birth. In the galley scene, Lepidus is eager to know more about Egyptian marvels:

LEPIDUS. You've strange serpents there?

ANTHONY. Ay, Lepidus.

LEPIDUS. Your serpent of Egypt is bred now of your mud by the operation of your sun; so is your crocodile. (2.7.24-27)

Anthony's vague reply seems to satisfy him as it reinforces his credulity. The ancient Egyptians thought that serpents, scorpions, crocodiles and the like hatched from the slime of the Nile under the action of the sun, and this belief was absorbed by Renaissance Europe. This passage has thus often been studied in connection with Aristotelian hylomorphism, ${ }^{13}$ a theory according to which natural bodies all consist of form and matter and in which slime plays the role of feminine matter (hyle) and the sun that of the male shaping power (morphe). ${ }^{14}$ Yet rather than trying to demonstrate the validity of this theory, Anthony (like Shakespeare) uses it to serve his own cause, seeing himself as the solar force and impregnator of Egypt while he assimilates Cleopatra to the Nile. In 
Alexandria, the Roman general thus presents himself as a godlike figure endowed with the mighty power of making things and creatures grow or else rot away.

That Anthony should identify with this omnipotent sun from which all life originates is made quite clear when he pleads with Cleopatra to allow his imminent departure to Rome:

\author{
[...] By the fire \\ That quickens Nilus' slime, I go from hence \\ Thy soldier-servant, making peace or war \\ As thou affects. (1.3.68-71)
}

In the tragedy's astronomical imagery, Cleopatra is generally vested with the attributes of Isis, the moon goddess, while her lover is associated with the sun. Here, as Anthony rather evasively alludes to spontaneous generation, he actually implies that the sun-i.e. himself-is what brings life to an Egyptian queen implicitly associated with the Nile.

Shakespeare's European contemporaries shared the idea that the river Nile was especially fecund. Giambattista Della Porta's Magia naturalis (1558), for example, paid specific attention to the Nile and explained how "the heat of the Sun enliv[ed] those moisture that lay in the tumors of the earth, like fertile seeds in the belly of their mother". ${ }^{15}$ Interestingly, in The Faerie Queene, Spenser similarly evokes the fecundity of the Nile when he compares the birth of Belphoebe and Amoret to the myriad creatures born from the mud. ${ }^{16}$ Yet "this analogy also recalls the repugnance of Error's brood", which the poet links to the ooze of the Nile, ${ }^{17}$ a parallel between mud and error found in many writings of the period..$^{18}$ So, for an early modern audience, the muddy ground of the Alexandrian environment in Shakespeare's tragedy must also have symbolised Anthony and Cleopatra's confused, slippery relationship indirectly referred to through the image of sinking sands.

Added to the presumably weakening effects of a hot, sluggish climate such as Egypt's, this idea is to be associated with the geography of hell. "O, my oblivion is a very Anthony" (1.3.91), Cleopatra jeeringly declares as she denounces her lover's departure for Rome. If after connoting its fecundity in the play, the Nile now stands for the nothingness of existence (the nihil), it also symbolises the river Lethe (2.7.107), the stream of oblivion in the underground ${ }^{19}$ : with this parched landscape where an omnipotent, all-engulfing river flows through the land, Shakespeare does not just make heat a marker of sensuality, but turns it into a mirror of hell. A hellish disruption indeed soon becomes general in Alexandria where the lovers inhabit a riparian area between land and water where, as a result, they find it difficult to hold on to firm ground and avoid the "quicksands" (2.7.58) of their unstable union.

7 The ontological instability which characterises the "inimitable life" of the Alexandrian pair as well as the Egyptian world picture finds its counterpart in the Epicurean philosophy which sees life as a flux in which "the primal particles of things / Are all in motion". ${ }^{20}$ "Nature", Lucretius asserts, "is ever changing and compelling / All that exists to alter". ${ }^{21}$ In Anthony and Cleopatra, Egypt's mud contributes to creating Cleopatra's boundless environment. It keeps shaping and un-shaping reality, not unlike the shifting clouds mentioned by Anthony when he says that "[s]ometimes we see a cloud that's dragonish" and gives the same cloud the shape of a bear, a lion, a citadel, a rock, or a mountain (4.14.2-11). The clouds create and un-create their forms in the sky of Egypt just 
like the mud keeps refashioning the ground of Egypt. Anthony offers a serious hint when he explains to a sceptical Octavius Caesar:

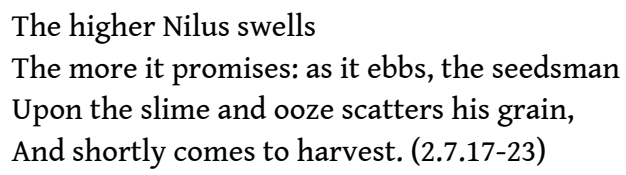

Beyond the agricultural information they provide, these erotically loaded lines ${ }^{22}$ are suggestive of the intense physical relationships and of the immoderate sexual life of the two title-parts. Yet the word "seedsman" also points to another interpretive track. The English word used as an equivalent for the Greek atomoi was not the word atoms, but the word "seeds" 23 and it is worth noting that Lucretius himself never uses the word atomus in his poem, where the atoms are called semina rerum ("the seeds of things"). ${ }^{24}$ So, in Shakespeare, seeds and, by extension, grains and germens, can sometimes be perceived as half-veiled allusions to the atomist doctrine. Read from an Epicurean perspective, the above-quoted passage reveals the world as being both evanescent and placed in a constant de- and re-composition process. The "grain[s]" mentioned by Anthony refer to the atoms composing the universe of pagan Alexandria, i.e. the void ${ }^{25} /$ nihil of Egypt's atmosphere. Seen in this way, the ooze of the Nile is neither debasing nor destructive. It simultaneously shapes and dissolves things and beings alike, melting and changing them as swiftly as the clouds in the air.

\section{Cleopatra's passions and emotions}

Slimy Egypt can therefore be seen both as a locus of tensions which abolishes the frontier between life and death and as a tabula rasa where nothing tangible ever remains, and this physical and cultural environment has a strong impact on Cleopatra's changing passions and emotions. Let us first remember that she is an eastern heroine. Indeed, the east imagined and idealised more than ten years earlier in A Midsummer Night's Dream takes shape in Anthony and Cleopatra, and it definitely fails to appear as promising as in Titania's glowing evocation of her friend the Indian votaress, since Egypt is as desperately muddy as the Athenian forest. But its recurrent flooding is to be considered less a climatic catastrophe than an agricultural blessing since the mud serves to fertilise rather than destroy the earth in this land of overflowing excess. ${ }^{26}$ Inseparable from the Nile river which gives the country its identity, Egypt as a southern region was associated with extreme heat, so that the climatic conditions of Alexandria partly explained the alleged indolence and sluggishness of its inhabitants. Those were typically feminine features according to Johann Weyer's De praestigiis daemonum ("On the Illusions of the Demons", 1563), a treatise which established a false etymological connection between mulier, the Latin word for "woman," and mollities, i.e. softness. ${ }^{27}$ This misogynistic commonplace was sometimes complicated by a no less popular (and no less false) etymology deriving mulier from mollis aer (soft air). ${ }^{28}$ In the context of Shakespeare's tragedy, such beliefs provide us with a valuable climatic portrait of the Egyptian queen, seen as both airy and soft. Like water and fire, air in the play is repeatedly associated with Cleopatra (5.2.88), while Anthony first seems to belong to the earth (1.1.37). ${ }^{29}$ As to Cleopatra's softness, it is of course partly produced by the "o'erflowing Nilus" (1.2.48) that seems to liquefy human and non-human entities alike. ${ }^{30}$ Significantly, when she hears of Anthony's second 
marriage after reluctantly listening to the messenger, the hurt queen conjures up images of flooding:

MESSENGER. Should I lie, madam?

CLEOPATRA. O, I would thou didst,

So half my Egypt were submerged and made

A cistern for scaled snakes. Go, get thee thence! (2.5.94-96)

Shakespeare's heroine wants to hear a lie even if the submersion of her homeland is the price to pay. Water is indeed one of the main tropes sustaining the Egyptian rhetoric: the very idea of destruction is mostly seen in terms of flooding and all this humidity is interiorised by Cleopatra who conveys her chagrin through an imagery of wetness. In the same scene, she promises metaphoric hail to her messenger if he brings good news: "I'll set thee in a shower of gold, and hail / Rich pearls upon thee" (2.5.46-47). Playing once again with gender roles, the cajoling Cleopatra adopts a somewhat equivocal stance towards her messenger as she rewrites the myth of Danaë, playing the part of Jupiter who came to her in the form of a golden shower in order to impregnate her womb. ${ }^{31}$ Then, $\mathrm{w}$ hen Thidias begs to kiss her hand, she agrees and remembers the love of Julius Caesar (i.e. Octavius Caesar's great-uncle) who, as he thought of conquering new places, "rained kisses" upon her body (3.13.85). Later on, in one of her many hyperbolic tirades, rain turns into hail: "From my cold heart let heaven engender hail" (3.13.160), ${ }^{32}$ she declares, a statement that reinforces her self-portrayal as someone originally "cold in blood" (1.5.74). While being "cold in blood" may allude to sexual unresponsiveness-in her "salad days" (1.5.74), the queen of Egypt was no femme fatale ${ }^{33}$-it is also indicative of Cleopatra's inner temper. Similarly, the reference to her "cold heart" is less an image of her emotional indifference than of what was then thought to be a physiological reality.

In the Six livres de la République (1576), the French humanist Jean Bodin developed a theory of climate establishing a correlation between climate, topography, and humours. This view circulated widely in England as the Six livres were translated into English by Richard Knolles as early as 1606 . For Bodin, the "inhabitants of Affrike" have little heat inside because it is "exhaled by the heat and drought of the sunne: whereas the cold doth keepe in the heat in the Northerne regions" ${ }^{34}$ Cleopatra thus contains this coldness within her, which seems to trigger off some of her apocalyptic statements: the "pelleted storm" (i.e. hail storm) (3.13.166) she intends to generate, as she imagines it, will be "discandying" (i.e. melting") $)^{35}$ on Egypt and will kill the Egyptians. In other words, wetness and cold predominate in her speeches in spite (and because) of the hot climate she lives in. As a result, Shakespeare's heroine is constantly deregulated by her own meteorological system: "We cannot call her winds and waters sighs and tears; they are greater storms and tempests than almanacs can report. This cannot be cunning in her; if it be, she makes a shower of rain as well as Jove" (1.2.145-50). ${ }^{36}$

10 While in act 2, scene 5, Cleopatra implicitly compares herself to the boundless Jupiter, Enobarbus, in these lines, already sees her in the role of this chief deity. More precisely, she is said to be equal to Jupiter Pluvius ("Jove"), the tutelary god of rain. However, the storms mentioned by Enobarbus are mere verbal tempests which are expressive of the queen's irascibility and which supersede actual rain and winds in the play. Indeed, no wind ever seems to blow in Egypt, where oars replace sails and where soft breezes give way to the irritating "breese", or gadfly, of Actium (3.10.14). In this faraway land, life seems paralysed and stagnating, thus causing Pompey to refer to it as "a Leth'd dullness" (2.1.27), while foreigners, unaccustomed to this hot and dry climate, feel despondent and 
"dejected" (4.13.7). Interestingly, the absence of wind symbolically suggests an ageing civilisation. In Book V of his poem, Lucretius explains for example that the world took its shape out of a storm (tempestas $)^{37}$ while in Shakespeare's Egypt, the storm has ceased, the four elements (4.11.1-3) have already been gathered, and in spite of the fecundity of Nile's slime, no real possibility of birth or rebirth seems available there. ${ }^{38}$ The only winds mentioned in the play are "lovesick" (2.2.201) and simply serve to waft the sweet scent of the barge's sails on the "River of Cydnus" (2.2.194). More refreshing currents of air are in fact generated by fans or by the pair of bellows to which Anthony is compared (1.1.9). Bound as the Roman general is "[t]o cool [the] gipsy's lust" (1.1.10), he has become entirely subservient to her desires. Yet the cool air he keeps blowing fails to appease her.

\section{Unbound/boundless Shakespeare: Anthony and Cleopatra, a cosmic drama?}

11 We have just seen that, according to the humoral theories of the time, the hot temperatures of Egypt account for Cleopatra's cold physiology and stormy life. The fact that she can be portrayed as "unbound" does not mean, therefore, that she is totally free: part of her existence is actually determined by environmental factors which shape her behaviour. Like the mud of the Nile river, she is fashioned by moisture.

If she is structurally earthbound, her lover, by comparison, reads and writes his destiny in the skies. Anthony's trajectory in the play marks a shift from Nile to sky, as it is that of a meteor, quick, bright, and short-lived. ${ }^{39}$ "[M]y good stars, [...] / Have empty left their orbs, and shot their fires / Into th'abysm of hell" (3.13.46-48), he declares in the third act, as if commenting on his own fall. Surprisingly, the erring, falling stars that shoot through the tragedy have only attracted only few substantial analyses. ${ }^{40}$ It is therefore worth noting that on top of their biblical connotation (they indeed recall John's vision in the Book of Revelation) and of their obvious link with the theme of hubris, "fallen" or "falling" stars were then seen as one of the celestial wonders of the time. Falling stars are for instance given a precise definition in Thomas North's translation of Plutarch's Lives, one of Shakespeare's main sources:

For they say, that those which we call falling starres, be no fluxions nor deriuacions of the fire elementorie, which are put out in the ayer, [...]: nor also an inflammation or combustion of any parte of the ayer, which by her to ouermuch quantity doth spread vpwardes: but they are celestiall bodies, which by some slackenes of strength, or falling from the ordinary course of heauen, are throwen and cast downe here beneath, not alwayes in any parte of the earth inhabited, but more ofter abroade in the great Occean sea, which is the cause that we do not see them. ${ }^{41}$

Far from Rome and the so-called "civilised" Roman world, Anthony indeed falls "from the ordinary course" of heaven until Cleopatra, through her own suicide, ultimately turns this fall into an apotheosis-and this paradigmatic shift turns what could have remained a relatively mundane Roman play into a much more complex cosmic drama.

The Egyptian queen first "expands" the image of the falling star as she literally sees her lover's death as part of a larger phenomenon entailing "the destruction of the heavenly bodies". ${ }^{42}$ She, as a result, implores the sun to depart from its sphere and leave the earth in total darkness: 
O sun,

Burn the great sphere thou mov'st in, darkling stand

The varying shore o'th'world! (4.16.10-12)

In the rather comic first half of the play, Cleopatra still has a limited vision of existence; she concentrates on her own native land and sees destruction in terms of flooding (2.5.94-96). In the tragic second half, as she broadens her view and focuses on a Ptolemaic cosmology, she then sees destruction in terms of burning. Once again, she is caught between two contradictory trends that reflect her paradoxical personality. On the one hand, she longs for airy elevation and cosmic grandeur; on the other, she feels attracted by a latent subterranean force. "Our strength is all gone into heaviness" (4.16.35), she bemoans for example as her lover dies under her eyes. Yet immediately after Anthony has passed away, she describes the world as a levelled place devoid of wonders: "And there is nothing left remarkable / Beneath the visiting moon" (4.16.69-70). The sublunary world is now turned upside down: what is of interest is what occurs in the sky, Anthony's new playground.

Such an emphasis on the unbound, infinite cosmic forces of the world is accompanied in the play by apocalyptic allusions to cracks and dis-location (in the etymological sense of the word) which gradually replace the melting images prevailing in the tragedy's first half. As often happens in Shakespeare, it is a mere servant who proves particularly clearsighted and who somehow guesses the forthcoming etymological disaster (i.e. stars straying from their trajectories) as early as act 2, scene 2: "To be called into a huge sphere, and not to be seen to move in't, are the holes where eyes should be, which pitifully disaster the cheeks" (2.7.14-16). The eyeless face evokes, of course, a Renaissance vanitas and aptly suggests the transience of life. But the space/body analogy also follows here the general trend observed in the maps that circulated in early modern England, which not only commodified space but also treated countries as human bodies. ${ }^{43}$ Anthony's grotesque body, ready to burst open, already takes on a co(s)mic dimension here: dislocation, in this case, is to be understood both in its etymological and usual senses. The motif, which has now turned tragic, is also hinted at in act 4, when Anthony muses upon the drifting clouds: "the rack dislimns" (4.15.10), ${ }^{44}$ he says, hinting at a dislimbed body, notably because of its proximity with the word "rack" which then designated an instrument of "torture" (4.15.46). ${ }^{45}$ Destruction verges on self-destruction when, in the following scene, Anthony exclaims: "O, cleave my sides! / Heart, once be stronger than thy continent, / Crack thy frail case!" (4.15.39-41, my emphasis). "Crack" and "cleave": these are the very verbs found in King Lear, yet another Lucretian tragedy. ${ }^{46}$ "Crack nature's moulds" Lear implores (3.2.8), begging "oak-cleaving thunderbolts" (3.2.5) to strike the earth. The same eschatological violence is at work in Anthony and Cleopatra. But while in King Lear, it was externalised and conveyed through the wind and the rain, it is here completely internalised and only betrayed by Anthony's rhetoric: the storm strikes within. The atmosphere, as a result, proves stifling. Eventually, the theme resurfaces in Octavius Caesar's speech when he learns about Anthony's death:

The breaking of so great a thing should make

A greater crack. The round world

Should have shook lions into civil streets,

And citizens to their dens. The death of Anthony

Is not a single doom, in the name lay

A moiety of the world. (5.1.14-19) 
Yet at the very end of the play, anger and pain are sublimated. Anthony's face morphs into the scintillating heavens and he continues to exist in the poetic image sustained in Cleopatra's consciousness:

His face was as the heavens, and therein stuck A sun and moon, which kept their course and lighted The little 0 , the earth. (5.2.78-80)

In such an anthropomorphic cosmology, there are no longer any barriers between physical and celestial bodies. Cleopatra's lines take on quasi-mystical inflexions and, in retrospect, they give a new meaning to Anthony's initial challenge to Cleopatra: "Then must thou need find out new heaven, new earth" (1.1.17). This longing for a cosmic voyage transcending the limits of the earth looked like wishful thinking at the beginning. Yet what first seemed devoid of sense suddenly takes on a tragic significance at the end. Re-membering her lover, the whore of Egypt shapes him anew and gives him fresh life. Gender roles are once again inverted as, this time, she takes on the role of the sun giving shape to mud and dust.

\section{Conclusion: the play's epistemological shift}

The tension between building and dissolution in the tragedy is therefore resolved to the detriment of "monument[s]" (4.16.8): in a play where everything melts, the most impressive of "citadel[s]" (4.15.4) can only be conjured up in the sky. While Octavius Caesar appears as the chief winner of the play, it is not he whom the audience will remember, but Anthony and Cleopatra. Shakespeare's unbound heroes have turned their earthly defeat into a heavenly triumph and manage to show that death is not an absolute end but a new beginning. Caesar stands for a finite universe, delimited by neat boundaries, organised along his political views. By contrast, Anthony and Cleopatra both reject the "Cartesian mind-body split" ${ }^{47}$ and promote instead an infinite universe such as the one described in Epicurus' Letter to Herodotus:

\section{[...] the universe is infinite. For that which is bounded has an extremity, and the extremity is seen against something else: (but the universe is not seen against something else): therefore, since it has no extremity, it has no boundary; and, since it has no boundary, it must be infinite and not bounded. 48}

Matter and empty space broadly define what Shakespeare's Egypt stands for. Cleopatra, famously characterised by her "infinite variety" (2.2.243), has certainly taken the full measure of the magnitude of the void by making the Nile/nihil an extension of her personality. Not only is she endowed with the traditional attributes of femininity (she is moist and soft like the river Nile) but she is also defined by a constitutive emptiness which leaves her permanently unsatisfied.

In conclusion, my contention is that the main epistemological shift of the play is localised in Egypt, and that it marks the transition from the hedonistic philosophy of festive Alexandria to an Epicurean one, signalling a gradual change from pleasure to ataraxia. In Anthony and Cleopatra, where everything melts and dissolves, life is defined by its mutability and its shiftiness. Such shiftiness is symbolised by the Nile as much as by the clouds in Egypt's sky. From act 4 onwards, the Nile becomes less prominent while the sky 
begins to appear as an alternative place enabling men to escape from the dungy earth of Egypt. As the space of metamorphosis and of possible re-creation(s), it becomes part and parcel of an erotic and apocalyptic cosmography, where whores become horses and sticky mud turns into multiform clouds. The only way out which is offered to the desperate title-parts, Shakespeare tells us, is away into the sky, the true alchemist of the play, able to transmute hail into sun rays, and a frustrating existence into an eternal, infinite afterlife. "Death", Lucretius writes, does not "destroy the particles of matter". It simply "recombines one element with another". ${ }^{49}$

\section{NOTES}

1. The issues tackled here are further developed in Sophie Chiari, Shakespeare's Representation of Weather, Climate and Environment. The Early Modern "fated sky", Edinburgh, Edinburgh University Press, 2019.

2. I rely on the following edition: William Shakespeare, Anthony and Cleopatra, ed. Michael Neill, Oxford, Oxford University Press, 1994. Other references to Shakespeare are to The Complete Works, ed. Stanley Wells, Gary Taylor, John Jowett and William Montgomery, Oxford, Clarendon Press, 2005 ( $2^{\text {nd }}$ edition).

3. Plutarch, "The Life of Octavius Caesar Augustus," trans. Thomas North, in Narrative and Dramatic Sources of Shakespeare, 8 volumes, ed. Geoffrey Bullough, The Roman Plays, Routledge and Kegan Paul, 1977, vol. 8, p. 322.

4. In his Planetomachia ("War of the Planets"), Robert Greene summarises the general suspicion concerning Epicurus: "[...] such is the perverse nature of man, that hee wholy forgetteth the cause of his Creation [...] And with the Epicures placeth his content in his Vineyards, and granaries, gaping after pelfe, and thinking his contemplation high enough in gazing after the painted shadowes of fading riches [...]". See Nandini Das (ed.), Robert Greene's Planetomachia (1585), Aldershot, Ashgate, 2007, p. 9.

5. On Epicure's impact and, by extension, Lucretius' influence upon Shakespeare's contemporaries, see David Norbrook, Stephen Harrison, and Philip Hardie (ed.), Lucretius and the Early Modern, Oxford, Oxford University Press, 2015.

6. On Epicureanism in Shakespeare's Roman plays, see also Julian C. Rice, "Julius Caesar and the Judgment of the Senses", Studies in English Literature, 1500-1900, Vol. 13, No. 2, Elizabethan and Jacobean Drama (Spring, 1973), p. 238-255.

7. Dan Brayton, "Shakespeare and Slime: Notes and the Anthropocene", in Ecological Approaches to Early Modern English Texts. A Field Guide to Reading and Teaching, ed. Jennifer Munroe, Edward J. Geisweidt, and Lynne Bruckner, Farnham, Ashgate, 2015, p. 85 (81-90).

8. Cf. 5.2.7. The $O E D$ records the first usage of the adjective "dungy" as meaning "[o]f the nature of dung; abounding in dung" $(O E D, 1)$ in Anthony and Cleopatra. It must therefore have caught the audience's attention, even though it had already been known as a synonym for "foul or filthy" or "vile, defiling" (OED, 2) since the fifteenth century. Still according to the $O E D$, "dung" had been used since the eleventh century to designate the "[e]xcrementitious and decayed matter employed to fertilize the soil".

9. On the importance of dung as manure in early modern England, see Leona J. Skelton, Sanitation in Urban Britain, 1560-1700, London, Routledge, 2016, p. 44. 
10. In the very English forest of A Midsummer Night's Dream, Titania complains that the "nine men's morris is fill'd up with mud" (2.1.98), for instance, and in The Merry Wives of Windsor, Mistress Ford alludes to a "muddy ditch close by the Thames' side" (3.3.13).

11. In the Bible, one of the dreams of Nebuchadnezzar (Dan. 2:33) gives rise to the description of a huge statue with feet of iron mixed with clay.

12. Gabriel Egan, Green Shakespeare: From Ecopolitics to Ecocriticism, London, Routledge, 2006, p. 110. 13. See Aristotle, The Generation of Animals, trans. A.L. Peck, Loeb Classical Library, Cambridge, Mass., Harvard University Press, 1943, Book 3, Chapter 11, 762a19-28. Aristotle insists on the fact that pneuma, in water, helps to spark life by permeating matter.

14. See Aristotle, History of Animals, trans. D.M. Balme, Loeb Classical Library, Cambridge, Mass., Harvard University Press, 1991, 539a18-26.

15. Quoted in William Eamon, Science and the Secrets of Nature. Books of Secrets in Medieval and Early Modern Culture, Princeton, Princeton University Press, 1994, p. 216.

16. Edmund Spenser, The Faerie Queene, ed. A.C. Hamilton, London, Longman, (1977) 1998, Book III, Canto vi, Stanza 8, 1. 7-9: "So after Nilus inundation, / Infinite shapes of creatures men do fynd, / Informed in the mud, on which the Sunne hath shynd".

17. Susan C. Staub, "While She Was Sleeping: Spenser's 'goodly storie' of Chrysogone" in Maternity and Romance Narratives in Early Modern England, eds. Karen Bamford and Naomi J. Miller, London, Routledge, (2015) 2016, p. 26 (13-32).

18. Mud as a symbol of error was still used by John Milton, especially in his attacks against prelacy. For a detailed study of Milton's imagery, see Stephen B. Dobranski, The Cambridge Introduction to Milton, Cambridge, Cambridge University Press, 2012, chapter 3, especially p. 103.

19. On the association of the river Lethe (and, by extension, the river Nile) with hell, see Christopher Ivic's entry "Lethe" in Shakespeare and National Identity. A Dictionary, London, Bloomsbury, 2017, p. 136.

20. Lucretius, De rerum natura, trans. R.C. Trevelyan, Cambridge, Cambridge University Press, 1937, Book II, p. 54. After being rediscovered in January 1417 in a German monastery by the Florentine humanist Poggio Bracciolini, Lucretius' poem was widely discussed along the whole Renaissance period. See in particular Gerard Passannante, The Lucretian Renaissance. Philology and the Afterlife of Tradition, Chicago, The University of Chicago Press, 2011. For more on Lucretius' influence on Shakespeare, see Richard Allen Shoaf, Lucretius and Shakespeare on the Nature of Things, Newcastle upon Tyne, Cambridge Scholars Publishing, 2014, p. 11.

21. Lucretius, De rerum natura, Book V, op. cit., p. 207.

22. See Pauline Kiernan, Shakespeare's Theory of Drama, Cambridge, Cambridge University Press (1996), 2000, p. 161. As Kiernan argues, Anthony here sees the Nile's flow "as part of a sexual process, in which tumescence promises bountiful fertility". According to Kiernan, "Cleopatra is so completely identified with Egypt's source of fertility, the tumescent Nile [...] that Roman conquest of her Queen is made to seem more than a metaphor for a triumph of martial values, rational logic and measure over the feminine principles of mutable process, fluidity and overflowing generative matter". Yet the lovers' sexual life proves sterile, and the play as a whole is underpinned by an ambivalent imagery stressing appetite and fertility on the one hand, decay and sterility on the other.

23. On this, see Jonathan Pollock, "Of Mites and Motes: Shakespearean Readings of Epicurean Science", in Spectacular Science, Technology and Superstition in the Age of Shakespeare, ed. Sophie Chiari and Mickaël Popelard, Edinburgh, Edinburgh University Press, 2017, p. 123-124 (119-132).

24. See for instance Lucretius, De rerum natura, op. cit., Book II, p. 46.

25. This void is defined by Enobarbus as 'a gap in Nature' (2.2.225).

26. On this, see Barbara J. Bono, Literary Transvaluation. From Vergilian Epic to Shakespearean Tragicomedy, Berkeley, Los Angeles, University of California Press, 1984, p. 205. 
27. In this, Weyer followed Varro, Lactantius, and St Augustine before him. See Stuart Clark, Thinking with Demons: The Idea of Witchcraft in Early Modern Europe, Oxford, Oxford University Press, 1997, p. 118.

28. Cf. William Shakespeare, Cymbeline, ed. Roger Warren, Oxford, Oxford University Press, 1998, p. $263,5.4 .448-450$.

29. Marjorie Garber, Shakespeare After All, New York, Anchor Books, 2004, p. 726: "And of the fabled 'four elements' (earth, water, air, and fire), the last three are Cleopatra's just as the earth is Antony's."

30. See Aristotle, Meteorologica, trans. H.D.P. Lee, Harvard University Press, Loeb Classical Library, 1952, IV, chap. VI, p. 319.

31. This myth is briefly mentioned in Ovid, Metamorphoses, trans. Arthur Golding, ed. Madeleine Forey, London, Penguin, 2002, Book IV, lines 749-751, p. 143.

32. Significantly, this line is part of a broader passage in which she views her own death in terms of dissolution as she asks the sky to engender "hail" from her "heart" and "the first stone" to "[d]rop in [her]neck," wishing her life were "[d]issolve[d]" (3.13.160-163).

33. On this, see Gordon Williams, A Glossary of Shakespeare's Sexual Language, London, Athlone, 1997, p. 74. Williams explains that Cleopatra was "sexually unresponsive" in her youth.

34. Jean Bodin, The six bookes of a common-weale, trans. Richard Knolles, London, Printed by Adam Islip, 1606, STC ( $2^{\text {nd }}$ ed.) 3193, The Fifth Booke, chap. 1, p. 548.

35. Cf. Anthony's tirade: "The hearts / That spanieled me at heels, to whom I gave / Their wishes, do discandy, melt their sweets / On blossoming Caesar [...]" (4.13.20-23).

36. Curiously, the same thing applies for Octavia who also seems to have her own system. As he sees her crying, having to part from her brother, Anthony says that "The April's in her eyes; it is love's spring, / And these the showers to bring it on" (3.2.43-44).

37. On this, see Mary-Jane Rubenstein, Worlds without End. The Many Lives of the Multiverse, New York, Columbia University Press, 2014, p. 49.

38. Children, barely evoked (Caesarion is mentioned once in 3.13.163), are oddly absent from the play, as the lovers promote sex over fertility. Anthony proves utterly unable to start a new life in Orient.

39. Falling stars, in the early modern era, generally referred to meteorites. See William Fulke, A goodly gallerye with a most pleasaunt prospect, London, Printed by William Griffith, 1563 , STC ( $2^{\text {nd }}$ ed.) 11435, "Of shotyng and falling Starres", fol. 7v-8r.

40. On the cosmic imagery pervading the play, see for example Kenneth Muir, "The Imagery of Antony and Cleopatra", Kwartalnik Neofilologiczny 8 (1961), 249-264. Revised as "The High Roman Fashion", chapter 9 of Shakespeare the Professional and Related Studies, London, Heinemann, 1973, p. 158-170.

41. Plutarch, The lives of the noble Grecians and Romanes, op.cit., "The Life of Lysander," p. 486.

42. Katherine Vance MacMullan, "Death Imagery in Antony and Cleopatra", Shakespeare Quarterly, Vol. 14, No. 4 (Autumn, 1963), p. 407 (399-410).

43. On early modern cartography as an act achieving the commodification of space, see Edward Said, Nationalism, Colonialism and Literature, Derry, Field Day, 1988, p. 11-12. One of the most famous instances of this commodification is Sebastian Münster's Cosmographia (Basel, Heinrich Petri, 1544). The book came through eight editions in Münster's lifetime. The "Regina Europa" anthropomorphic map included in the book shows the body of a queen superimposed onto Europe (for an illustration from the 1570 edition, see: https://upload.wikimedia.org/wikipedia/ commons/8/86/Europe_As_A_Queen_Sebastian_Munster_1570.jpg).

44. In the 1988 Complete Works, the Oxford editors chose "distains" (for the Folio "dislimes"), a verb also retained in the 2005 edition. But the New Oxford Shakespeare edition of The Complete Works (2016) now gives precedence to "dislimns" over "distains". 
45. In his 1994 edition of the play, Michael Neill acknowledges his debt to Emrys Jones's 1977 Penguin edition: “[...] Jones detects word-play 'involving the idea of a body [...] being "dislimbed"-torn limb from limb-upon a rack" (p. 283, note to 4.15.10). For more on "dislimns" in connection with torture and with other "dis" prefix words in the play, see Maurice Charney, Wrinkled Deep in Time: Aging in Shakespeare, New York, Columbia University Press, 2009, p. 124.

46. For more on this, see Sophie Chiari, "Climate as Climax in Shakespeare's Plays", Shakespeare in Southern Africa. Journal of the Shakespeare Society of Southern Africa, 29, ed. Christopher Thurman, 2017, p. 12 (1-15).

47. Ibid., p. 7.

48. See Epicurus, Letter to Herodotus, 41-42, in The Epicurus Reader, trans. Brad Inwood and L.P. Gerson, Indianapolis, IN, Hackett, 1994. The theory put forward by Epicurus is used extensively by Lucretius in the first book of his De rerum natura.

49. Lucretius, De rerum natura, op. cit., Book II, p. 80.

\section{ABSTRACTS}

Negotiating with contradictory views of meteorology spread by classical writers, Shakespeare frequently relies in his plays on a rich weather imagery which conveys the anxieties of his contemporaries regarding destruction and infertility. Doing so, he manages to translate meteorological effects into dramatic affects. As a play scrutinizing unbound and exacerbated feelings in a hot and moist environment, Anthony and Cleopatra is a case in point. It features a heroine whose passionate outbursts and erotic drives are related to broader geo-humoral concerns and climatic issues. In this paper, I first explore the destructive yet paradoxically creative power of the Nile to see how Shakespeare reworks Cleopatra's liebestod before turning to the heroine's boundless emotions. I then analyse Shakespeare's vision of the boundless sky in a tragedy where, under the possible influence of Lucretius, the playwright changes the lovers' fall into an apotheosis. All in all, I propose to decentre the traditional readings of the play. So far, Cleopatra has often been perceived as an unbound femme fatale while her Roman lover has repeatedly been regarded as the embodiment of inconstancy ("O, my oblivion is a very Anthony", 1.3.91). Yet in the tragedy, I argue, versatility is first and foremost an environmental feature applying to Shakespeare's Egypt.

Puisant dans les approches contradictoires des questions météorologiques par les écrivains de l'Antiquité, Shakespeare développe dans ses pièces un riche réseau métaphorique et climatique qui traduit l'inquiétude de ses contemporains vis-à-vis des problèmes relatifs à la destruction et à l'infertilité, cela afin de transformer les images figées du temps météorologique en effets scéniques spectaculaires. Antoine et Cléopâtre, en tant que pièce s'intéressant au déchaînement des sentiments dans un environnement chaud et humide, en fournit l'éclatante démonstration : elle met à l'honneur une héroïne dont la passion et l'érotisme sont étroitement liées aux théories géo-humorales et climatiques de la Renaissance. Dans un premier temps, cet article explore donc le pouvoir tant destructeur que créateur du Nil pour voir comment Shakespeare explore la liebestod de Cléopâtre, avant d'analyser les émotions variées qu'elle incarne tour à tour dans la pièce. J'en viens ensuite à ce qui est la vision shakespearienne d'un ciel sans limite dans une tragédie où, peut-être en partie influencé par la philosophie lucrétienne, le dramaturge transforme la chute des amants en véritable apothéose. Une telle lecture permet en fin de 
compte de décentrer l'approche traditionnelle d'Antoine et Cléopâtre. Alors que l'on a souvent vu en Cléopâtre l'archétype de la femme fatale libre de toute entrave et en son amant l'incarnation de l'inconstance (« 0 , my oblivion is a very Anthony », I.iii.91), je montre dans cette étude que la versatilité et l'instabilité s'appliquent avant tout à l'environnement géographique et climatique de l'Égypte telle que Shakespeare la représente.

INDEX

Keywords: Anthony and Cleopatra, climate, cosmos, disaster, flooding, Lucretius, meteorology, mud, Nile, Shakespeare William, shiftiness, sky, star

Mots-clés: Antoine et Cléopâtre, boue, ciel, climat, cosmos, désastre, étoile, impermanence, inondation, Lucrèce, météorologie, Nil, Shakespeare William

\section{AUTHOR}

\section{SOPHIE CHIARI}

(Université Clermont Auvergne, IHRIM, UMR 5317) 